\title{
An Evaluation of Additivity Schemes for the Estimation of Heats of Formation of Distonic Radical Cationst
}

\author{
James W. Gauld, ${ }^{a}$ John L. Holmes ${ }^{b}$ and Leo Radom ${ }^{a, *}$ \\ ${ }^{a}$ Research School of Chemistry, Australian National University, Canberra, ACT 0200, Australia and ${ }^{\text {b Department of }}$ \\ Chemistry, University of Ottawa, Ottawa, Ontario, Canada, K1N 6N5
}

\begin{abstract}
Gauld, J. W., Holmes, J. L. and Radom, L., 1997. An Evaluation of Additivity Schemes for the Estimation of Heats of Formation of Distonic Radical Cations. - Acta Chem. Scand. 51: 641-645. C Acta Chemica Scandinavica 1997.

The validity of additivity schemes for the determination of the heats of formation of distonic radical cations, $\mathrm{CH}_{2}\left(\mathrm{CH}_{2}\right)_{n-1} \mathrm{OH}_{2}{ }^{+}(n=1-4)$, has been examined using high level [G2(MP2,SVP) and G2(MP2)] ab initio calculations. The additivity schemes in essence assume that either (a) the dissociation energy of a $\mathrm{C}-\mathrm{H}$ bond in a protonated molecule (e.g., $\mathrm{CH}_{3} \mathrm{OH}_{2}{ }^{+}$) is the same as that of the corresponding unprotonated molecule (e.g., $\mathrm{CH}_{3} \mathrm{OH}$ ), or that (b) the proton affinity of a radical (e.g., $\mathrm{CH}_{2}{ }^{\circ} \mathrm{OH}$ ) is the same as that of the corresponding molecule (e.g., $\mathrm{CH}_{3} \mathrm{OH}$ ). These assumptions are found not to hold well for $\alpha$-distonic radical cations (e.g., $\mathrm{CH}_{2} \mathrm{OH}_{2}{ }^{+}$), i.e., species for which the charge and radical sites are formally located on adjacent atoms $(n=1)$. However, they lead to reasonable estimates for the heats of formation of larger distonic radical cations $(n>1)$. A rationalization of these observations in terms of orbital interactions is presented.
\end{abstract}

Knowledge of the heats of formation $\left(\Delta H_{\mathrm{f}}\right)$ of ions is important in understanding gas-phase ionic processes. In this respect, a variety of experimental procedures have been used to obtain heats of formation for a large number of ions. ${ }^{1}$ However, in some instances the experimental determination of the heat of formation can be quite difficult and approximation schemes are used to obtain such information. ${ }^{2-5}$ These approximation schemes often exhibit quite useful accuracy.

Distonic radical cations (e.g., $\mathrm{CH}_{2} \mathrm{OH}_{2}{ }^{+}$), i.e., radical cations in which the charge and radical sites are formally separated, represent a class of ions for which the direct determination of $\Delta H_{\mathrm{f}}$ is not always straightforward. A principal reason is that distonic radical cations do not generally have stable neutral counterparts and are therefore often produced by more complex rearrangementfragmentation reactions. ${ }^{6,7}$ Moreover, any experimental determination of $\Delta H_{\mathrm{f}}$ (e.g., by measuring an appearance energy) requires that the pure distonic ion be unambiguously generated. An approximation scheme has therefore been used ${ }^{4-6,8,9}$ in which it is in essence assumed either that (a) the bond dissociation energy (BDE) of a $\mathrm{C}-\mathrm{H}$ bond in a protonated molecule (e.g., $\mathrm{CH}_{3} \mathrm{OH}_{2}{ }^{+}$) is the same as that for the corresponding unprotonated molecule (e.g., $\mathrm{CH}_{3} \mathrm{OH}$ ), or that (b) the proton affinity (PA)

\footnotetext{
* To whom correspondence should be addressed.

$\dagger$ Part of a lecture held at the 14th International Conference on Radical Ions, Uppsala, Sweden, July 1-5, 1996.
}

of a radical (e.g., $\mathrm{CH}_{2} \mathrm{OH}$ ) is the same as that for the corresponding molecule (e.g., $\mathrm{CH}_{3} \mathrm{OH}$ ). In this way, the heat of formation of a distonic radical cation can be estimated from generally known quantities. For example, the $\Delta H_{\mathrm{f}}$ of $\mathrm{CH}_{2} \mathrm{OH}_{2}{ }^{+}$can be obtained from the $\Delta H_{\mathrm{f}}$, $\mathrm{BDE}$ and PA of methanol on the basis of such assumptions (see Fig. 1).

There are examples in the literature where these assumptions have appeared to be satisfactory, but it has been anticipated that they may fail when the charge and radical sites are adjacent (i.e., for $\alpha$-distonic radical cations).$^{5,6}$ Indeed, a recent experimental study ${ }^{10}$ found the proton affinity of $\mathrm{CH}_{2}{ }^{\circ} \mathrm{OH}\left(695 \mathrm{~kJ} \mathrm{~mol}^{-1}\right)$ to differ markedly from that of the neutral analogue $\mathrm{CH}_{3} \mathrm{OH}$

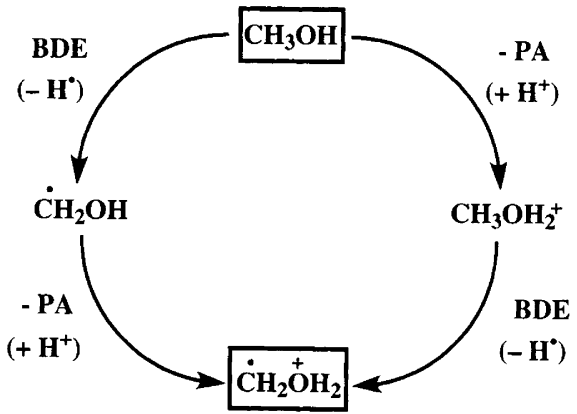

Fig. 1. Thermochemical cycle for the determination of the heat of formation of $\mathrm{CH}_{2} \mathrm{OH}_{2}{ }^{+}$using known thermochemical data and additivity approximations. 
$\left(760 \mathrm{~kJ} \mathrm{~mol}^{-1}\right)$, casting general doubt on the validity of assumption (b) above.

In the present study, we have employed high levels of $a b$ initio molecular orbital theory to examine the reliability of these approximation schemes. Specifically, we have calculated and compared bond dissociation energies for the terminal $\mathrm{C}-\mathrm{H}$ bonds in the series $\mathrm{CH}_{3}\left(\mathrm{CH}_{2}\right)_{n-1} \mathrm{OH}$ and $\mathrm{CH}_{3}\left(\mathrm{CH}_{2}\right)_{n-1} \mathrm{OH}_{2}{ }^{+}$, and proton affinities at oxygen in the series $\mathrm{CH}_{3}\left(\mathrm{CH}_{2}\right)_{n-1} \mathrm{OH}$ and $\mathrm{CH}_{2}\left(\mathrm{CH}_{2}\right)_{n-1} \mathrm{OH}$ $(n=1-4)$.

\section{Theoretical procedures}

Standard $a b$ initio molecular orbital calculations ${ }^{11}$ were carried out with the GAUSSIAN 92/DFT ${ }^{12}$ and GAUSSIAN $94^{13}$ series of programs. Geometries and harmonic vibrational frequencies were optimized using both Hartree-Fock (HF) and second-order MøllerPlesset (MP2) theory, with the 6-31G(d) basis set.

Theoretical heats of formation, bond dissociation energies and proton affinities were obtained using slightly modified G2(MP2) ${ }^{14}$ and G2(MP2,SVP) ${ }^{15,16}$ procedures. These methods are similar in approach and accuracy to $\mathrm{G} 2^{17}$ but are computationally less demanding. All three procedures effectively correspond to QCISD $(T) / 6-311+G(3 d f, 2 p)$ energy calculations on MP2(full)/6-31G(d) optimized structures, with zeropoint energy corrections determined from scaled (by $0.8929) \mathrm{HF} / 6-31 \mathrm{G}(\mathrm{d})$ vibrational frequencies and a so-called higher level correction term included. Our minor modification corresponds to using optimized geometries obtained at the MP2/6-31G(d) level with the frozen-core approximation, i.e., $\mathrm{MP} 2(\mathrm{fc}) / 6-31 \mathrm{G}(\mathrm{d})$, rather than MP2(full)/6-31G(d). This is not expected significantly to affect the results. Restricted (RHF, RMP2) and unrestricted (UHF, UMP2) procedures were used for closed- and open-shell systems, respectively. The frozen-core approximation (fc) was used throughout.

Standard procedures ${ }^{18}$ were used to obtain heats of formation at $0 \mathrm{~K}\left(\Delta H_{\mathrm{f} 0}\right)$ from the calculated total energies via atomization reactions, and $\Delta H_{\mathrm{f} 298}$ values were obtained from the $\Delta H_{\mathrm{f} 0}$ values using our computed [scaled HF/6-31G(d)] vibrational frequencies. Throughout this paper, energy comparisons refer to $298 \mathrm{~K}$ values.

In an initial set of calculations, $\Delta H_{\mathrm{f} 298}, \mathrm{BDE}$ and PA values were obtained, as appropriate, for $\mathrm{CH}_{3}\left(\mathrm{CH}_{2}\right)_{n-1} \mathrm{OH}, \quad \mathrm{CH}_{3}\left(\mathrm{CH}_{2}\right)_{n-1} \mathrm{OH}_{2}{ }^{+}$and $\mathrm{CH}_{2}{ }^{-}-$ $\left(\mathrm{CH}_{2}\right)_{n-1} \mathrm{OH}(n=1-3)$ at both the G2(MP2) and G2(MP2,SVP) levels, based on global minimum energy structures determined at the MP2/6-31G(d) level of theory. The G2(MP2) and G2(MP2,SVP) results were found to be in very good agreement with one another in all cases. The computationally cheaper G2(MP2,SVP) procedure was therefore used in subsequent calculations.

In a second set of calculations, BDEs and PAs were calculated at the G2(MP2,SVP) level for systems constrained to idealized all-trans conformations, possessing a plane of symmetry along the $\mathrm{C}-\mathrm{C}_{n-1}-\mathrm{O}$ chain [referred to as the all-trans $\left(C_{\mathrm{s}}\right)$ conformations]. In addition, the range of systems examined was extended to $n=4$. The idealized extended chain conformations were chosen in these calculations in order to examine the validity of the approximation schemes in the absence of effects associated with conformational changes. For $\mathrm{CH}_{2}{ }^{\circ} \mathrm{OH}$, however, there exists no minimum energy structure (i.e., global or local minimum) at either the HF/6-31G(d) or MP2/6-31G(d) level that satisfies these criteria, and the normal optimized structure was therefore used.

\section{Results and discussion}

Comparison of calculated and experimental heats of formation. A comparison of calculated [G2(MP2,SVP) and G2(MP2)] and experimental ${ }^{1,19}$ heats of formation is presented in Table 1 . There is uniformly good agreement between the G2(MP2) and G2(MP2,SVP) values, the largest difference being just $4.3 \mathrm{~kJ} \mathrm{~mol}^{-1}$ (for $\mathrm{CH}_{3} \mathrm{OH}_{2}{ }^{+}$). There is also good agreement in general between the theoretical and experimental heats of formation, with most values agreeing to within $\pm 10 \mathrm{~kJ} \mathrm{~mol}^{-1}$. However, larger differences are found for $\mathrm{CH}_{2} \cdot \mathrm{OH}$ (8.2-11.3 $\left.\mathrm{kJ} \mathrm{mol}^{-1}\right), \quad \mathrm{CH}_{2} \mathrm{CH}_{2} \mathrm{OH} \quad(31.9-32.0 \mathrm{~kJ}$ $\left.\mathrm{mol}^{-1}\right), \quad \mathrm{CH}_{2} \cdot\left(\mathrm{CH}_{2}\right)_{2} \mathrm{OH} \quad\left(17.7-18.7 \mathrm{~kJ} \mathrm{~mol}^{-1}\right)$ and $\mathrm{CH}_{2} \cdot\left(\mathrm{CH}_{2}\right)_{2} \mathrm{OH}_{2}{ }^{+}\left(18.6-20.8 \mathrm{~kJ} \mathrm{~mol}^{-1}\right)$. In the case of $\mathrm{CH}_{2} \cdot \mathrm{OH}$, our calculated heat of formation $(-14.6$ to $\left.-17.7 \mathrm{~kJ} \mathrm{~mol}^{-1}\right)$ is in better agreement with more recent experimental determinations, which predict $\Delta H_{\mathrm{f} 298}$ to lie in the region of -12 to $-20 \mathrm{~kJ} \mathrm{~mol}^{-1} \cdot 20-24$ For $\mathrm{CH}_{2}{ }^{\cdot} \mathrm{CH}_{2} \mathrm{OH}, \mathrm{CH}_{2} \cdot\left(\mathrm{CH}_{2}\right)_{2} \mathrm{OH}$ and $\mathrm{CH}_{2} \cdot\left(\mathrm{CH}_{2}\right)_{2} \mathrm{OH}_{2}{ }^{+}$, a re-examination of the experimental heats of formation $^{19,25}$ would seem desirable. As a result of these comparisons, we have chosen to use our calculated energies (rather than the experimental energies) as the basis for subsequent analysis of bond dissociation energies and proton affinities.

Table 1. Calculated ${ }^{a}$ and experimental ${ }^{b}$ heats of formation at $298 \mathrm{~K}\left(\mathrm{~kJ} \mathrm{~mol}^{-1}\right)$.

\begin{tabular}{lccc}
\hline Molecule & G2(MP2,SVP) & G2(MP2) & Exptl. \\
\hline $\mathrm{CH}_{3} \mathrm{OH}$ & -204.9 & -208.7 & -201.6 \\
$\mathrm{CH}_{3} \mathrm{CH}_{2} \mathrm{OH}$ & -238.6 & -240.1 & -234.8 \\
$\mathrm{CH}_{3}\left(\mathrm{CH}_{2}\right)_{2} \mathrm{OH}$ & -260.0 & -259.0 & -254.8 \\
$\mathrm{CH}_{2} \cdot \mathrm{OH}$ & -14.6 & -17.7 & -25.9 \\
$\mathrm{CH}_{2} \cdot \mathrm{CH}_{2} \mathrm{OH}$ & -24.1 & -24.0 & $-56^{c}$ \\
$\mathrm{CH}_{2} \cdot\left(\mathrm{CH}_{2}\right)_{2} \mathrm{OH}$ & -49.3 & -48.3 & $-67^{c}$ \\
$\mathrm{CH}_{3} \mathrm{OH}_{2}{ }^{+}$ & 571.5 & 567.2 & 567 \\
$\mathrm{CH}_{3} \mathrm{CH}_{2} \mathrm{OH}_{2}{ }^{+}$ & 515.5 & 513.4 & 507 \\
$\mathrm{CH}_{3}\left(\mathrm{CH}_{2}\right)_{2} \mathrm{OH}_{2}{ }^{+}$ & 485.9 & 486.3 & 476 \\
$\mathrm{CH}_{2} \cdot \mathrm{OH}_{2}{ }^{+}$ & 820.4 & 817.1 & 815 \\
$\mathrm{CH}_{2} \cdot \mathrm{CH}_{2} \mathrm{OH}_{2}{ }^{+}$ & 730.8 & 729.1 & 732 \\
$\mathrm{CH}_{2} \cdot\left(\mathrm{CH}_{2}\right)_{2} \mathrm{OH}_{2}{ }^{+}$ & 693.2 & 695.4 & 714 \\
\hline
\end{tabular}

${ }^{a}$ Calculated using the lowest energy conformers located on the MP2/6-31G(d) potential energy surface (see the text). ${ }^{b}$ Experimental values taken from Ref. 1, unless otherwise noted. ${ }^{c}$ From Ref. 19. 
Bond dissociation energies. The calculated values of the terminal $\mathrm{C}-\mathrm{H}$ bond dissociation energies for the lowest energy conformations of $\mathrm{CH}_{3}\left(\mathrm{CH}_{2}\right)_{n-1} \mathrm{OH}$ and $\mathrm{CH}_{3}\left(\mathrm{CH}_{2}\right)_{n-1} \mathrm{OH}_{2}{ }^{+}(n=1-3)$ are presented in Table 2 . It is clear that the $\mathrm{C}-\mathrm{H}$ BDE of protonated methanol $\left(\mathrm{CH}_{3} \mathrm{OH}_{2}{ }^{+}\right)$is not equal to that of methanol $\left(\mathrm{CH}_{3} \mathrm{OH}\right)$. The calculated difference is $58.6-59.0 \mathrm{~kJ} \mathrm{~mol}^{-1}$, with the value in protonated methanol being much higher than in neutral methanol. However, in ethanol and its protonated form (i.e., $n=2$ ), the calculated $\mathrm{C}-\mathrm{H}$ bond dissociation energies differ by just $0.3-0.6 \mathrm{~kJ} \mathrm{~mol}^{-1}$, while for propanol and its protonated form $(n=3)$, the difference is only $3.2-3.6 \mathrm{~kJ} \mathrm{~mol}^{-1}$. Thus, the terminal $\mathrm{C}-\mathrm{H}$ BDEs for the protonated alcohols are very close to those of the alcohols for all but the first pair in the series, even when conformational differences are allowed.

The trends in BDEs with increasing $n$, for the all-trans $\left(C_{\mathrm{s}}\right)$ conformations, are shown diagrammatically in Fig. 2. The results for $n=1-3$ parallel those observed in the conformationally unconstrained systems (Table 2). Thus, the $\mathrm{C}-\mathrm{H}$ bond dissociation energies in $\mathrm{CH}_{3} \mathrm{OH}$ and $\mathrm{CH}_{3} \mathrm{OH}_{2}{ }^{+}$are clearly significantly different. However, as soon as one or more methylene groups are interposed between the site of bond dissociation and the

Table 2. Calculated $\mathrm{C}-\mathrm{H}$ bond dissociation energies at $298 \mathrm{~K}$

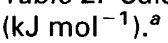

\begin{tabular}{llll}
\hline Precursor & Product & $\begin{array}{l}\text { G2 } \\
\text { (MP2,SVP) }\end{array}$ & $\begin{array}{l}\text { G2 } \\
\text { (MP2) }\end{array}$ \\
\hline $\mathrm{H}-\mathrm{CH}_{2} \mathrm{OH}$ & $\mathrm{CH}_{2} \cdot \mathrm{OH}$ & 408.2 & 408.9 \\
$\mathrm{H}-\mathrm{CH}_{2} \mathrm{OH}_{2}{ }^{+}$ & $\mathrm{CH}_{2} \cdot \mathrm{OH}_{2}{ }^{+}$ & 466.8 & 467.9 \\
$\mathrm{H}-\mathrm{CH}_{2} \mathrm{CH}_{2} \mathrm{OH}$ & $\mathrm{CH}_{2} \cdot \mathrm{CH}_{2} \mathrm{OH}$ & 432.7 & 433.3 \\
$\mathrm{H}-\mathrm{CH}_{2} \mathrm{CH}_{2} \mathrm{OH}_{2}{ }^{+}$ & $\mathrm{CH}_{2} \cdot \mathrm{CH}_{2} \mathrm{OH}_{2}{ }^{+}$ & 433.3 & 433.6 \\
$\mathrm{H}-\mathrm{CH}_{2}\left(\mathrm{CH}_{2}\right)_{2} \mathrm{OH}^{+}$ & $\mathrm{CH}_{2} \cdot\left(\mathrm{CH}_{2}\right)_{2} \mathrm{OH}^{+}$ & 428.8 & 429.0 \\
$\mathrm{H}-\mathrm{CH}_{2}\left(\mathrm{CH}_{2}\right)_{2} \mathrm{OH}_{2}{ }^{+}$ & $\mathrm{CH}_{2} \cdot\left(\mathrm{CH}_{2}\right)_{2} \mathrm{OH}_{2}{ }^{+}$ & 425.2 & 425.8 \\
\hline
\end{tabular}

${ }^{a}$ Calculated using the lowest energy conformers located on the MP2/6-31G(d) potential energy surface (see the text).

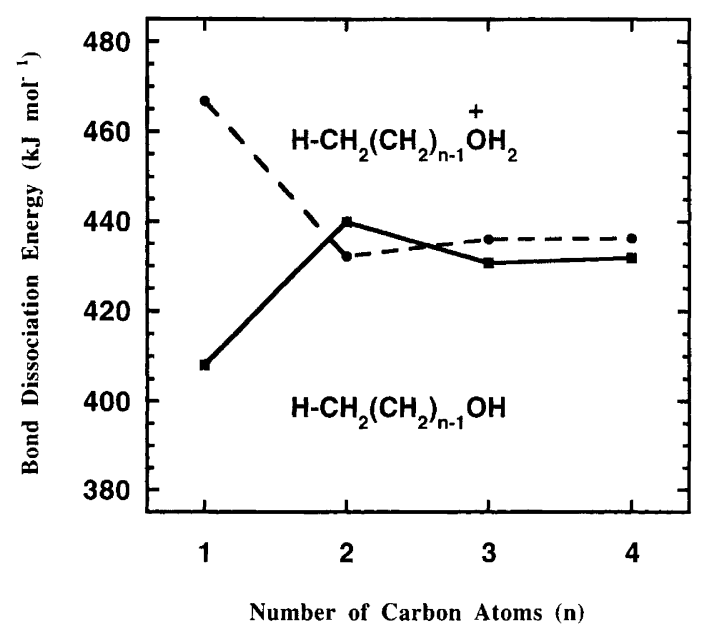

Fig. 2. Calculated G2(MP2,SVP) bond dissociation energies for all-trans $\left(C_{\mathrm{s}}\right)$ conformers of $\mathrm{H}-\mathrm{CH}_{2}\left(\mathrm{CH}_{2}\right)_{n-1} \mathrm{OH}$ and $\mathrm{H}-\mathrm{CH}_{2}\left(\mathrm{CH}_{2}\right)_{n-1} \mathrm{OH}_{2}{ }^{+}$for $n=1-4$. oxygen atom, there is an immediate and marked reduction in the difference in the BDEs between the neutrals and their protonated analogues. The two curves in Fig. 2 both appear to converge quickly towards a limiting value of approximately $435 \mathrm{~kJ} \mathrm{~mol}^{-1}$. The assumption that the bond dissociation energy of a $\mathrm{C}-\mathrm{H}$ bond in the protonated alcohol is the same as that for the corresponding unprotonated alcohol thus fails for $n=1$ but appears to hold well for $n>1$. The possible failing of such approximations for $n=1$ has been suggested previously. ${ }^{6}$ The convergence behavior for other related properties of distonic ions has been discussed previously. ${ }^{26}$

The trends shown by the two bond dissociation curves in Fig. 2 suggest that the 'anomalous' behavior in the BDEs of methanol and protonated methanol is due mainly to short-range effects. A rationalization is provided by orbital interaction arguments ${ }^{27}$ involving the p-type lone pair orbital on the oxygen atom in neutral methanol (see Fig. 3). Hyperconjugation between this orbital and the appropriate pseudo- $\pi^{*}$ antibonding orbital of the methyl group leads to weakening of the $\mathrm{C}-\mathrm{H}$ bonds. Protonation of the hydroxy group (as in $\mathrm{CH}_{3} \mathrm{OH}_{2}{ }^{+}$) lowers the energy of the p-type lone pair orbital on oxygen. This leads to a reduced hyperconjugative interaction with the methyl $\pi^{*}$ orbital and hence leads to a reduction in the extent of bond weakening. In addition, contributions from the 'no-bond' resonance structure $\mathrm{CH}_{3}{ }^{+} \mathrm{OH}_{2}$ result in a lengthening of the $\mathrm{C}-\mathrm{O}$ bond in $\mathrm{CH}_{3} \mathrm{OH}_{2}{ }^{+}$(to $1.518 \AA$ ), also leading to a reduction in the extent of bond weakening. Thus, protonation of methanol will lead to an increase in the $\mathrm{C}-\mathrm{H}$ homolytic bond dissociation energy. As soon as one or more methylene groups are interposed, however, the possibility of hyperconjugative interaction with oxygen is effectively removed and hence the effect of protonation on the BDE becomes very small. Alternative arguments based on electronegativity effects have been used in previous studies of the effects of protonation on bond dissociation energies. ${ }^{28}$

The hyperconjugative bond weakening in methanol is reflected in a $\mathrm{C}-\mathrm{H}_{2}$ bond length of $1.097 \AA$ compared with a length of $1.090 \AA$ for the $\mathrm{C}-\mathrm{H}_{1}$ bond (see Fig. 3). The latter cannot interact with the p-orbital at oxygen because of orthogonality of the potentially interacting orbitals; only interaction with the less effective $\mathrm{sp}^{2}$-type

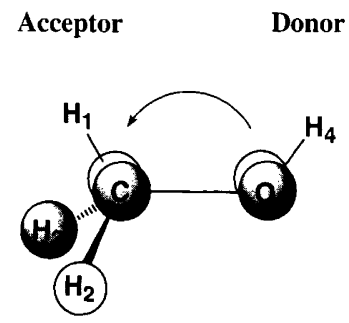

Fig. 3. Schematic representation of hyperconjugative interaction between the p-type lone pair on oxygen and the pseudo- $\pi^{*}$ antibonding orbital of the methyl group in methanol. 
donor orbital at oxygen is possible. In contrast, the $\mathrm{C}-\mathrm{H}$ bonds in protonated methanol are 1.086-1.087 $\AA$. So the $\mathrm{C}-\mathrm{H}$ bonds in $\mathrm{CH}_{3} \mathrm{OH}_{2}{ }^{+}$are shorter than those in $\mathrm{CH}_{3} \mathrm{OH}$, consistent with the reduction in hyperconjugative bond weakening. In the ethanol-protonated ethanol pair and in the extended all-trans $\left(C_{\mathrm{s}}\right)$ conformations of propanol-protonated propanol and butanol-protonated butanol, all the $\mathrm{C}-\mathrm{H}$ bond lengths lie within the fairly narrow range of 1.091-1.094 $\AA$, reflecting the absence of strong hyperconjugative interaction with oxygen. On the other hand, in the unconstrained protonated propanol structure, one of the $\mathrm{C}-\mathrm{H}$ bonds is as long as $1.097 \AA$, possibly as a result of direct interaction with the bonds at the oxygen center.

Proton affinities. The calculated values of the proton affinities at oxygen for the lowest energy conformations of $\mathrm{CH}_{3}\left(\mathrm{CH}_{2}\right)_{n-1} \mathrm{OH}$ and $\mathrm{CH}_{2} \cdot\left(\mathrm{CH}_{2}\right)_{n-1} \mathrm{OH}(n=1-3)$ are presented in Table 3 and show exactly parallel behavior to that noted for the bond dissociation energies. For the smallest species, $\mathrm{CH}_{3} \mathrm{OH}$ and $\mathrm{CH}_{2} \mathrm{OH}$, we see a significant difference in the proton affinities of $58.6-59.1 \mathrm{~kJ} \mathrm{~mol}^{-1}$. For those systems corresponding to $n=2$ and 3, i.e., ethanol and propanol and their corresponding radicals, the differences are markedly smaller (0.3-0.7 and 3.2-3.5 $\mathrm{kJ} \mathrm{mol}^{-1}$, respectively).

The trends in PAs with increasing $n$ for the all-trans $\left(C_{\mathrm{s}}\right)$ conformations are shown in Fig. 4 . Again, the results parallel those (Table 3 ) for the conformationally unconstrained systems with $n=1-3$. Thus, as the distance between the site of protonation and the radical site is increased, the proton affinities of the radicals immediately approach the values for the corresponding neutrals. The proton affinities increase gradually with $n$ and appear to be converging but it is not clear how far our values for $n=3$ and 4 would lie from the ultimate $(n=\infty)$ limit.

The rapid approach of the two curves in Fig. 4 to one another, suggests again that short-range effects are primarily responsible for the behavior with respect to protonation of $\mathrm{CH}_{2} \mathrm{OH}$ vs. $\mathrm{CH}_{3} \mathrm{OH}$. This can be rationalized in terms of a two-center-three-electron interaction. In $\mathrm{CH}_{2} \mathrm{OH}$, the lone pair on the oxygen interacts with the singly occupied p-type orbital on the carbon, the two orbitals being aligned almost parallel to one another.

Table 3. Calculated proton affinities at $298 \mathrm{~K}\left(\mathrm{~kJ} \mathrm{~mol}^{-1}\right){ }^{a}$

\begin{tabular}{llll}
\hline Neutral species & & $\mathrm{G} 2$ & $\mathrm{G} 2$ \\
& Protonated species & (MP2,SVP) & (MP2) \\
\hline $\mathrm{CH}_{3} \mathrm{OH}$ & $\mathrm{CH}_{3} \mathrm{OH}_{2}^{+}$ & 754.3 & 754.9 \\
$\mathrm{CH}_{2} \cdot{ }^{+} \mathrm{OH}$ & $\mathrm{CH}_{2} \cdot \mathrm{OH}_{2}{ }^{+}$ & 695.7 & 695.8 \\
$\mathrm{CH}_{3} \mathrm{CH}_{2} \mathrm{OH}$ & $\mathrm{CH}_{3} \mathrm{CH}_{2} \mathrm{OH}_{2}{ }^{+}$ & 776.6 & 777.2 \\
$\mathrm{CH}_{2} \cdot \mathrm{CH}_{2} \mathrm{OH}$ & $\mathrm{CH}_{2} \cdot \mathrm{CH}_{2} \mathrm{OH}_{2}{ }^{+}$ & 775.9 & 776.9 \\
$\mathrm{CH}_{3}\left(\mathrm{CH}_{2}\right)_{2} \mathrm{OH}$ & $\mathrm{CH}_{3}\left(\mathrm{CH}_{2}\right)_{2} \mathrm{OH}_{2}{ }^{+}$ & 784.7 & 785.3 \\
$\mathrm{CH}_{2} \cdot\left(\mathrm{CH}_{2}\right)_{2} \mathrm{OH}$ & $\mathrm{CH}_{2} \cdot\left(\mathrm{CH}_{2}\right)_{2} \mathrm{OH}_{2}{ }^{+}$ & 788.2 & 788.5 \\
\hline
\end{tabular}

${ }^{a}$ Calculated using the lowest energy conformers located on the MP2/6-31G(d) potential energy surface (see the text).

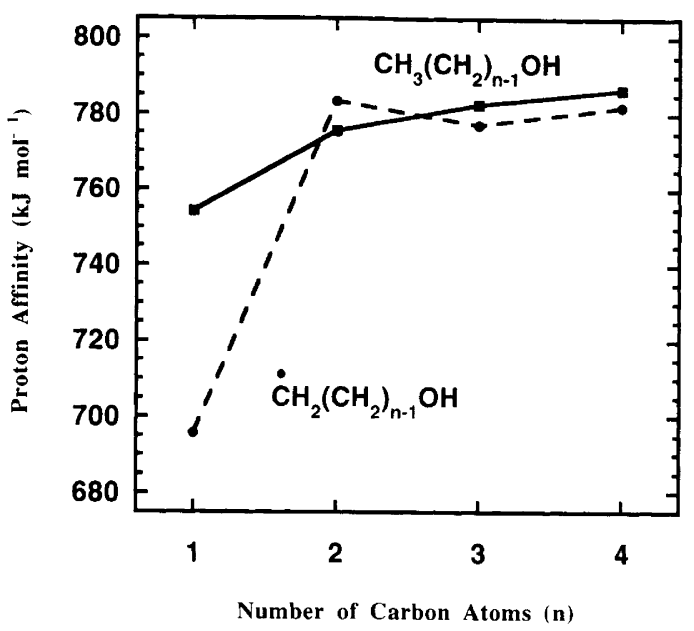

Fig. 4. Calculated G2(MP2,SVP) proton affinities for all-trans $\left(C_{\mathrm{s}}\right)$ conformers of $\mathrm{CH}_{3}\left(\mathrm{CH}_{2}\right)_{n-1} \mathrm{OH}$ and $\mathrm{CH}_{2} \cdot\left(\mathrm{CH}_{2}\right)_{n-1} \mathrm{OH}$ for $n=1-4$.

This three-electron interaction results in a delocalization of the lone pair on the oxygen across the $\mathrm{C}-\mathrm{O}$ bond, lowering its energy and making it less available for protonation. Thus, protonation in $\mathrm{CH}_{2} \mathrm{OH}$ is less favourable than in $\mathrm{CH}_{3} \mathrm{OH}$. As $n$ is increased, i.e., as soon as one or more methylene groups are interposed between the oxygen atom and the radical site, the interaction between the oxygen lone pair and the singly occupied orbital at carbon is drastically reduced. Thus, one can expect the proton affinities of the radicals immediately to approach those of the corresponding neutrals, as is observed (see Table 3 and Fig. 4).

\section{Conclusions}

Our results indicate that the approximations:

$$
\begin{aligned}
& \mathrm{BDE}\left[\mathrm{H}-\mathrm{CH}_{2}\left(\mathrm{CH}_{2}\right)_{n-1} \mathrm{OH}_{2}{ }^{+}\right] \\
& \quad \approx \mathrm{BDE}\left[\mathrm{H}-\mathrm{CH}_{2}\left(\mathrm{CH}_{2}\right)_{n-1} \mathrm{OH}\right]
\end{aligned}
$$

and

$$
\mathrm{PA}\left[\mathrm{CH}_{2} \cdot\left(\mathrm{CH}_{2}\right)_{n-1} \mathrm{OH}\right] \approx \mathrm{PA}\left[\mathrm{CH}_{3}\left(\mathrm{CH}_{2}\right)_{n-1} \mathrm{OH}\right]
$$

are poor when $n=1$, i.e., these approximations should not be used in estimating heats of formation for $\alpha$-distonic radical cations such as $\mathrm{CH}_{2} \mathrm{OH}_{2}{ }^{+}$. However, the approximations are found to hold well (i.e., to within $4 \mathrm{~kJ} \mathrm{~mol}^{-1}$ ) when $n>1$, i.e., when one or more methylene groups is interposed between the 'active sites'. These results can be rationalized using orbital interaction arguments.

Acknowledgements. The award of a Visiting Fellowship to J.L.H. by the Research School of Chemistry of the Australian National University, and a generous allocation of time on the Fujitsu VP-2200 of the Australian National University Supercomputer Facility, are gratefully acknowledged. 


\section{References}

1. Lias, S. G., Bartmess, J. E., Liebman, J. F., Holmes, J. L., Levin, R. D. and Mallard, W. G. J. Phys. Chem. Ref. Data, Suppl. 17 (1988) 1.

2. Holmes, J. L., Fingas, M. and Lossing, F. P. Can. J. Chem. 59 (1981) 80.

3. Holmes, J. L., Lossing, F. P., Terlouw, J. K. and Burgers, P. C. J. Am. Chem. Soc. 104 (1982) 2931.

4. Holmes, J. L. and Lossing, F. P. Int. J. Mass Spectrom. Ion Proc. 92 (1989) 111.

5. Holmes, J. L. Adv. Mass Spectrom. 11 (1989) 53.

6. Hammerum, S. Mass Spectrom. Rev. 7 (1988) 123.

7. Kenttämaa, H. I. Org. Mass Spectrom. 29 (1994) 1.

8. Benoit, F. M., Harrison, A. G. and Lossing, F. P. Org. Mass Spectrom. 12 (1977) 78

9. Wesdemiotis, C., Danis, P. O., Feng, R., Tso, J. and McLafferty, F. W. J. Am. Chem. Soc. 107 (1985) 8059.

10. Mourgues, P., Audier, H. E., Leblanc, D. and Hammerum, S. Org. Mass Spectrom. 28 (1993) 1098.

11. Hehre, W. J., Radom, L., Schleyer, P. v. R. and Pople, J. A. Ab Initio Molecular Orbital Theory, Wiley, New York 1986.

12. Frisch, M. J., Trucks, G. W., Schlegel, H. B., Gill, P. M. W., Johnson, B. G., Wong, M. W., Foresman, J. B., Robb, M. A., Head-Gordon, M., Replogle, E. S., Gomperts, R., Andres, J. L., Raghavachari, K., Binkley, J. S., Gonzalez, C., Martin, R. L., Fox, D. J., DeFrees, D. J., Baker, J., Stewart, J. J. P. and Pople, J. A. GAUSSIAN 92/DFT, Gaussian Inc., Pittsburgh, PA 1993.

13. Frisch, M. J., Trucks, G. W., Schlegel, H. B., Gill, P. M. W., Johnson, B. G., Robb, M. A., Cheeseman, J. R., Keith, T. A., Petersson, G. A., Montgomery, J. A., Raghavachari, K., Al-Laham, M. A., Zakrzewski, V. G., Ortiz, J. V., Foresman, J. B., Cioslowski, J., Stefanov, B. B.,
Nanayakkara, A., Challacombe, M., Peng, C. Y., Ayala, P. Y., Chen, W., Wong, M. W., Andres, J. L., Replogle, E. S., Gomperts, R., Martin, R. L., Fox, D. J., Binkley, J. S., DeFrees, D. J., Baker, J., Stewart, J. P., HeadGordon, M., Gonzalez, C. and Pople, J. A. GAUSSIAN 94, Gaussian Inc., Pittsburgh, PA 1995.

14. Curtiss, L. A., Raghavachari, K. and Pople, J. A. J. Chem. Phys. 98 (1993) 1293.

15. Smith, B. J. and Radom, L. J. Phys. Chem. 99 (1995) 6468.

16. Curtiss, L. A., Redfern, P. C., Smith, B. J. and Radom, L. J. Chem. Phys. 104 (1996) 5148.

17. Curtiss, L. A., Jones, C., Trucks, G. W., Raghavachari, K. and Pople, J. A. J. Chem. Phys. 94 (1991) 7221.

18. Nicolaides, A., Rauk, A., Glukhovtsev, M. N. and Radom, L. J. Phys. Chem. 100 (1996) 17460.

19. Holmes, J. L., Lossing, F. P. and Mayer, P. M. J. Am. Chem. Soc. 113 (1991) 9723.

20. Dobe, S. Z. Phys. Chem. 175 (1992) 123.

21. Ruscic, B. and Berkowitz, J. J. Phys. Chem. 97 (1993) 11451.

22. Espinosa-García, J. and Olivares del Valle, F. J. J. Phys. Chem. 97 (1993) 3377.

23. Traeger, J. C. and Holmes, J. L. J. Phys. Chem. 97 (1993) 3453.

24. Kuo, S., Zhang, Z., Klemm, R. B., Liebman, J. F., Stief, L. J. and Nesbitt, F. L. J. Phys. Chem. 98 (1994) 4026.

25. Holmes, J. L. and Lossing, F. P. Can. J. Chem. 60 (1982) 2365.

26. Yates, B. F., Bouma, W. J. and Radom, L. Tetrahedron 42 (1986) 6225.

27. Radom, L. Prog. Theor. Org. Chem. 3 (1981) 1.

28. Boyd, S. L., Boyd, R. J., Bessonette, P. W., Kerdraon, D. I. and Aucoin, N. T. J. Am. Chem. Soc. 117 (1995) 8816.

Received September 19, 1996. 